\title{
SELF-RESTRAINT AND MORALITY
}

\author{
YOTAM BENZIMAN \\ https:/ / orcid.org/0000-0002-9602-8766 \\ Sapir Academic College \\ Department of Philosophy \\ Hof Ashkelon \\ Israel \\ yotam.benziman@mail.huji.ac.il
}

\section{Article info \\ CDD: 121}

Received: 26.06.2020; Revised: 12.09.2020; Accepted: 14.09.2020

https://doi.org/10.1590/0100-6045.2020.V43N3.YB

\section{Keywords \\ Ethics \\ Self-restraint \\ Temptation}

\begin{abstract}
The item was in the news. A public official said that he would hire a male rather than a female driver, because following the growing influence of the \#MeToo movement, hiring a man would be safer. That way nobody would accuse him of harassment. The official's declaration aroused justified public criticism. Being a public official, he must be committed to equality-in-hiring practices. But suppose that it were a private individual, who wanted to do his utmost to keep away from temptation. It might seem that there is nothing wrong with that: he is free to hire whomever he wishes, and his caution is justified: planning ahead and resisting temptation are marks of rationality and personhood, in Harry Frankfurt's sense of the term. But why should one be so cautious to begin with? Challenging other philosophical analyses of temptation, I argue that temptations are hardly irresistible. We should all take responsibility for our actions and behavior. It is a moral duty to control ourselves and not let others pay the price for our shortcomings. This notion is both Kantian, as it emphasizes autonomy, and Aristotelian: it urges us to work on our virtues.
\end{abstract}




\section{SELF-RESTRAINT AND MORALITY}

The item was in the news. A public official said that he would hire a male driver rather than a female one. Following the growing influence of the \#MeToo movement, he explained, hiring a man would be safer. That way nobody would spread rumors, or suspect him, or accuse him, of harassment. The official's declaration aroused public criticism, and rightly so. Being a public official, he must be committed to equality-in-hiring practices. He is not allowed to discriminate against certain sectors of society - in this case, women. Also, in his behavior he seemed to be implying that women's complaints about harassment tend to be ungrounded. Allegedly, whenever a man is alone with a woman, in a secluded space such as a car, she can accuse him of attacking her, and he would have no witness to prove otherwise. Such an attitude rests on a stereotypical view of women. If you are not a harasser, we should say to this person, you have no reason to worry. Nobody will accuse you of a misdemeanor you did not commit. Just keep behaving in your ordinary, civilized manner, and nothing bad will ensue.

But suppose that we change the example. It is not a public official now, but a private wealthy individual who is hiring a chauffeur, and is free to choose whomever he likes for the job. Assume further that it is not a false complaint made by his employee that the person is concerned about, but rather his own behavior. No, he is no harasser. But he is a single, lonely man, and he wants to do his utmost to keep away from temptation, to make sure that he doesn't take advantage of an intimate situation he is not used to. As a measure of selfrestraint, he decides to avoid hiring a female driver, just to be on the safe side. Isn't such self-restraint morally praiseworthy? In what follows I will address this issue. Tackling questions regarding self-restraint and temptation, 
I'll answer in the negative. To conclude my analysis, I will get back to the wrongness of the official's behavior as manifested in his declaration in the original case.

\section{SELF-RESTRAINT AS RATIONAL}

Suppose that I know I will be tempted to do something which would be detrimental. Taking precautions in advance would seem the obvious thing to do. The most famous example is Odysseus. Circe, warning him from the sirens' malicious powers, tells him that "there is no homecoming for the man who draws near them unawares and hears the Sirens' voices; no welcome from his wife, no little children brightening at their father's return. For with their high clear song the Sirens bewitch him." 1 Therefore, Odysseus instructs his men: "You must bind me very tight, standing me up against the step of the mast and lashed to the mast itself so that I cannot stir from the spot. And if I beg and command you to release me, you must tighten and add to my bonds." $2 \mathrm{He}$ seems to be doing the right thing. Bonding yourself so as not to surrender to such temptation is a mark of rationality. It attests to your planning ahead, to your applying the right means to achieve your end.

It also attests to your personhood, if we adhere to Harry Frankfurt's analysis of this concept. Frankfurt regards "having second-order volitions [...] as essential to being a person." 3 A volition involves wanting a certain desire to be your will. A will is "an effective desire - one that moves (or

${ }^{1}$ Homer, The Odyssey, p. 130.

2 Ibid, p. 132.

${ }^{3}$ Harry Frankfurt, "Freedom of the Will and the Concept of a Person," p. 10. 
will or would move) a person all the way to action." 4 And Frankfurt's well-known example of the physician treating his narcotic patients fits perfectly with this characterization.

Indeed, Frankfurt uses this example to introduce the notion of not wanting your desire to be an effective one. In order to better understand what his patients are going through, the physician wants to know what it feels like to want the drug. He wants to have this feeling, without being moved to action, i.e., without its making him actually take the drug. Indeed, "he may prudently arrange to make it impossible for him to satisfy the desire he would have if his desire to want the drug should in time be satisfied." 5

But that means that the physician has an effective desire: the desire not to take the drug. He carefully conducts his plans so that this desire is fulfilled, i. e. that the drug would not be available for him when he desires to take it. He distances himself from what might tempt him. This distancing attests to his personhood. It is rational and prudent. There is nothing wrong with it.

The physician's example might seem idiosyncratic, as it involves a situation most of us are unlikely to face. Most jobs, we should hope, do not entail the notion of wanting to succumb to taking an addictive drug as part of their routine. It should be noted, however, that a strategy analogous to the one we have been considering is rational and prudent for all of us, as our daily habit. We are all familiar with the phenomenon of having the urge to take just one more glass of wine at dinner, for example, despite our knowing that it might be unhealthy for us. Michael Bratman has claimed that the rational thing to do in such a case is to avoid reconsidering our initial decision not to take the glass, so as

4 Ibid, p. 8.

5 Ibid, p. 9.

Manuscrito - Rev. Int. Fil. Campinas, v. 43, n. 3, pp. 55-71, Jul.-Sep. 2020. 
not to be tempted. ${ }^{6}$ As with the physician, constructing our plans so as not to yield to temptation is a mark of sound reason.

\section{TEMPTATION}

If restraining yourself so as to avoid temptation is rational, it might seem that the person in our hypothetical example is acting prudently when he resolves to employ a male driver rather than a female one, and thus his conduct is not morally flawed but quite the opposite. In order to pave the way for showing that his conduct is flawed nonetheless, it would be useful to analyze what temptation actually consists in, and why it is morally questionable.

The notion of temptation has hardly been discussed by philosophers. J. P. Day is one of the few who did address this issue. He analyzes temptation as a relation between two people: a tempter and a temptee. According to his interpretation, "tempting is morally wrong because it is morally wrong to try to cause TE [the temptee] to do what is morally, or prudentially, or aesthetically, or legally wrong." 7 This entails that you cannot tempt somebody to do the right thing. Yet, this is surely mistaken. Suppose that you strongly

6 This is Bratman's view of rationality, as manifested in his Intentions, Plans, and Practical Reason. He uses the glass-of-wine example in a later article, where he speaks specifically about temptation (Michael E. Bratman, "Temptation and the Agent's Standpoint"). Bratman's theory in this article is that the best strategy would be not to ignore the temptation, but rather to anticipate your future regret with regards to succumbing to it. However, the essence of the prudent thing to do, i.e. stick to your original plans, remains.

${ }^{7}$ J. P. Day, “Temptation," p. 177.

Manuscrito - Rev. Int. Fil. Campinas, v. 43, n. 3, pp. 55-71, Jul.-Sep. 2020. 
resist returning something you hold to its lawful owner. Suppose that all attempts to reason with you and convince you to do the right thing fail. But I can tempt you to return the valuable object by offering you something that I know you have been craving for your entire life. It should be clear that I did not try to cause you to do "what is morally, or prudentially, or aesthetically wrong."

It seems to follow that if I tempt you to do the right thing, tempting you is good, while if I tempt you do the wrong thing, then it is bad. A. T. Nuyen's analysis of temptation, however, is at odds with this conclusion. He claims that temptation should not be "assessed in terms of the goodness or badness of the act that the tempter induces the temptee to perform." Instead, his suggestion is that "tempting is wrong only when the tempter uses his or her subject as a means to his or her own end, and only as a means." 8

But consider Nuyen's own example, concerning the police tempting a person to inform on her criminal friends. As he has it, "the end that the police aim at - the reduction of crimes, making the streets safer, is something for the 'victim' of the temptation as well (indeed, for all of us, including the informant's criminal friends.)" something misleading in this example. If we stick to Nuyen's terminology, we should be asking whether the police here use the informant as a means to their (the police's) "own end(s)." However, what are those ends exactly? The police, by definition, is an organization that is supposed to serve the public. It does not have its "own ends" as separate from those of the public, or of all of us. The "reduction of crimes" is of course an end worth pursuing. It is worth pursuing because it is good for all of us. Thus, if tempting the criminal

8 A. T. Nuyen, , “The Nature of Temptation," p. 100.

${ }^{9}$ Ibid, p. 101. 
to inform on her friends is good, it is so because it serves us all. But that means that the conclusion that it is good has to do with assessing it "in terms of the goodness or badness of the act that the tempter induces the temptee to perform," which is what Nuyen's analysis wished to avoid.

Claiming, like Nuyen, that the informer's betraying her friends is "something for" these very friends, is unconvincing. Go and ask these people how they feel about their friend's informing on them. Indeed, the problem with informing has to do with the fact that the informer does not "go and ask" them. He does not care about their feelings or their interests. He is not interested in their ends as such. Nuyen proposes what he terms "a Kantian account,"10 but it is misdirected. The problem with temptation is not that the tempter uses the temptee for the former's ends. It is not his ends that we should be considering, but rather the ends of his target. Tempting involves not taking the temptee's ends seriously - in this case, the informant's. This is not to say that tempting is never the right thing to do. In this case it seems to be acceptable, perhaps even praiseworthy. The good result - arresting a criminal - justifies it, because it outweighs the wrongness involved in the temptation itself, and the fact that the temptee was led to betray her friends. However, the act of temptation itself is, indeed, problematic.

Paul Hughes' analysis describes this wrongness in a manner similar to what I have been suggesting here. His portrayal, like Nuyen's, is "Kantian in spirit," but seems more accurate: "In manipulating another person we treat him as a means to an end, rather than as an end in himself. This is a violation of moral agency because it compromises moral autonomy. Respecting the moral autonomy of others requires that we allow them to make their own moral decisions." And this means that even tempting a person to

10 Ibid, p. 100.

Manuscrito - Rev. Int. Fil. Campinas, v. 43, n. 3, pp. 55-71, Jul.-Sep. 2020. 
do the right thing is objectionable, because it consists of "the attempt to persuade him to act contrary to his beliefs about what he should do. If successful, such an effort results in his doing the right thing by a tempter's design, a scheme which robs him of the possibility of behaving in a morally worthy manner." 11

"If successful" indeed. But must it be successful? In a later article Hughes criticizes the notion of entrapment, claiming that certain temptations are simply irresistible. "It is the notion of deliberately and irresistibly tempting people that most clearly illuminates what is objectionable about entrapment."12 Providing strong temptations puts the temptee in a state of "volitional ambivalence," where he "cannot decisively and wholeheartedly identify with either of his conflicting first-order desires. This entails that a person in such a state is not autonomous and, thus, that the actions he performs are not freely chosen." 13 These claims echo Day's analysis. According to Day, "irresistible temptation compels by arousing an irresistible desire in TE [the temptee]."14 Other temptations, though not "irresistible," take place "when TE's desire and lowered resistance preclude deliberation and choice, so that he reacts automatically (instinctively) to the temptation." 15

I would like to suggest that both Day and Hughes are exaggerating. Most of us hardly face temptations that are irresistible. We all have our "deliberation and choice." This is, indeed, an important mark of our humanity, and I discuss

${ }^{11}$ Paul M. Hughes, “The Logic of Temptation,” pp. 97-98.

12 Paul M. Hughes, "What Is Wrong with Entrapment," p. 50.

13 Ibid, p. 54.

14 Day, "Temptation," p. 178.

15 Ibid, p. 177. 
this notion further in the next section. Male sexual desire, as described in the example at the outset of this paper, has sometimes been culturally assumed to be irresistible. This assumption has had broad consequences, both conceptually and practically, but has nevertheless no empirical foundation. ${ }^{16}$

If entrapment, in the sense Hughes uses the term, is wrong, it is not because of its facing the temptee with irresistible temptations, or ones that jeopardize his deliberation and choice. Rather, it has to do with what the tempter is trying to persuade the temptee to do. Entrapment is not a mere temptation. It is, as Hughes says, a temptation to "commit a crime." ${ }^{17}$ Committing a crime is both morally and legally wrong, and soliciting another to do so is a criminal offence. The wrongness lies with the content of what we are trying to tempt this person to do, rather than with his "volitional ambivalence."

\section{AGENCY AND RESPONSIBILITY}

We all have our volitional ambivalences. Each of us has his own weaknesses and might be tempted to act contrary to his best judgment. As Nuyen rightly claims, some temptations are not caused by a tempter. "[W] can perfectly well speak of a person who has decided to quit smoking, or drinking, being tempted to have a cigarette, or a drink, without being offered one. The cause of the temptation could well be purely internal." 18

${ }^{16}$ For a thorough critique see Jane H. Aiken, "Differentiating Sex from Sex: The Male Irresistible Impulse."

17 Hughes, "What Is Wrong with Entrapment,", p. 50.

${ }^{18}$ Nuyen, "The Nature of Temptation," p. 92. 
The supposed temptation we are dealing with is internal in this sense. Nobody is actually trying to tempt the wealthy individual. It is his inner desires that might cause him to be tempted. A respect for the agency of such a person would entail taking this internal struggle seriously. He plans his own life. He is capable of making decisions. He tries time and again to win. Sometimes he fails. He yields to that which he has sworn he wouldn't yield to, and he has to start all over again. This is what being a deliberating, thinking, contemplating person is all about. The "Kantian spirit" of which both Nuyen and Hughes speak has to mean that a person can hardly be manipulated to act in ways contrary to her own thinking. Even if she is mistaken about what's good for her, even if she misconstrues her way in life, it is her life and her decisions, not anybody else's.

In an imaginary world such as Odysseus', supernatural beings like the Sirens might "bewitch" you. This cannot happen in real life. In some extreme cases people might drug you or point a gun at you, thus forcing you to act as they please. But in ordinary cases it is for you to decide how to respond to their attempts to persuade you to act as they wish you to. In fact, this notion of agency lies at the core of the analyses of temptation we have been considering. For Hughes, a part of the "logic of temptation" is that "whether or not temptation occurs $[. .$.$] depends essentially on the$ psychology of the subject of temptation rather than on the actions of a tempter. Try as one might, nobody can tempt another person unless the psychological pre-conditions of being tempted are present, and these are, except in unusual cases, independent of the actions of a tempter."19 Similarly, Nuyen distinguishes between being a "temptee," which has to do with having a desire for some A, and being actually tempted, which means that one "resolves to satisfy the desire

19 Hughes, "the Logic of Temptation," p. 96.

Manuscrito - Rev. Int. Fil. Campinas, v. 43, n. 3, pp. 55-71, Jul.-Sep. 2020. 
for A, thus consciously giving up the resolve that conflicts with it, or modifying the mindset that conflicts with it." 20

"Resolve" has to do with action. It involves enacting one's will, and deciding firmly how to act. Thus, if you "resolve to satisfy the desire for A," while no illegitimate trick has been pulled on you, no lie was told, no information was distorted or withheld - who are you to blame but yourself? But going back to the example of the person contemplating which driver to hire, isn't that what he is supposing to begin with? It is himself that he is trying to educate. He knows that if he is tempted, he will have only himself to blame, and therefore decides not to put himself in danger. It is his own private decision. Remember also that we have changed the original case to that of a private individual, hence he is supposedly concerned only with his own conduct. My claim is that this private person's behavior is morally flawed.

The term I have used - "decides not to put himself in danger" - is instructive. Being alone in a vehicle with a person you might get attracted to is no danger. That hypothetical lady driver is not threatening whatsoever. Indeed, the exact opposite is true: her lonely employer is a potential threat to her. He holds himself back so that he does not do anything wrong to her, which is of course far better than if he were to actually attack her. But why should he assume that potentially harassing her is a viable option to begin with? Any thought on his part about fulfilling this option, even a vague and theoretical one, even one that is strongly subdued by measures taken by this individual, is morally wrong from the outset.

Saul Smilansky's article "Should I Be Grateful to You for Not Harming Me?" gives a positive answer to the question that appears in its title. According to Smilansky, "not

20 Nuyen, "The Nature of Temptation," p. 96. 
harming regularly requires concern and effort, and is clearly beneficial to people. To be ungrateful for such beneficial efforts is often not different in kind from ingratitude towards our (positive) beneficiaries." $21 \mathrm{He}$ goes on to say that "the effort involved in resisting temptation, and perhaps even in checking e.g. harmful irrational impulses, may merit gratitude as well." 22 According to this theory, we should admire any potential harasser and any other might-be wrongdoer for not causing any damage. More than that, suppose that a person is not a potential harasser, but an actual one. This would mean that he often finds it too hard to "check harmful irrational impulses." But staying with me alone in a dark room, he somehow managed to control himself and spare me, as he didn't do in other cases. If we follow Smilansky's logic, I should admire him for that and be grateful. Generalizing this example, we would get the result that the more dangerous one is, and the more potential threats one might make (either explicitly or implicitly), the more beneficial one might be towards a particular person by not executing these threats in a particular case, hence the more admirable one is in this particular case. But this is implausible.

Our portrayal of the case of the hypothetical individual hiring a driver does not go as far as Smilansky's theory suggests. Smilansky would have potential victims grateful to their potential aggressors for not attacking them. The private car owner in our example did not ask people to thank him for his self-control. Rather, I have described him as "supposedly concerned only with his own conduct." $\mathrm{He}$ does not ask anything of others. He just lives his private life.

${ }^{21}$ Saul Smilansky, "Should I Be Grateful to You for Not Harming Me?”, p. 593.

22 Ibid. 
But this is untrue. We all interact with each other. When one of us contemplates on whom he should hire as a driver, for example, he is involving other people in his plans. Deciding to hire A rather than B, because I might find it hard to resist B's charm and would unintentionally harm her, would mean asking $B$ to pay the price for my weakness.

This needs some further explanation. After all, it is not the case that $\mathrm{B}$ has a right to be hired by the person in our example. He is free to hire whomever he wants to. She might even be unaware of his resolution not to hire a woman. In what sense does she "pay the price"?

Suppose that the person did hire B. Every day he has the urge to harass her. Every day he succeeds in conquering this desire. Unbeknownst to her, B is in constant threat. This is far from what she deserves. Each and every one of us deserves to lead a safe and secure life, unthreatened by the misconduct of potential harassers.

But this last sentence is true regardless of whether or not $\mathrm{B}$ was actually hired by the wealthy individual. His deciding not to hire her, so as to avoid potential harassment, treats her as a potential victim. In this sense, she is asked to pay the price for his potential misconduct. He should be the one to take responsibility for his conduct. This should be the real meaning of the Kantian spirit of which we have spoken: a person should take responsibility for his or her own character traits. We might also call it an "Aristotelian spirit": one ought to cultivate one's virtues. One should be a decent, respectable person - a person whom nobody should fear to work for as a driver.

The specific virtues that come to mind with regards to the drivers' example would be temperance, continence, endurance. All three have been considered praiseworthy ever since Aristotle's analysis of them. But the "Aristotelian spirit" that I alluded to is broader than that. It has to do with the notion of phronesis, or practical wisdom, which governs 
the virtues in their entirety: learning what feelings are apt and where, and what actions, if any, should follow from them.

This should mean that each of us must attend first and foremost to her own personality. We should take seriously Hughes' notion of "the possibility of behaving in a morally worthy manner." But while Hughes sees this as a lesson for the tempter: don't divert others from so morally acting, I want to stress the lesson that the agent himself should learn: believe in your ability to so act. Construct your character so that it is stable. Do not even consider immoral actions as possibilities.

Note that this standard is not too hard to achieve. Some branches of virtue theory aim at constructing an ideally virtuous person, whom we should all try to emulate, or get as close to as we can. We cannot actually achieve his or her high stance, because none of us is perfect. But not-evencontemplating-to-harass-anybody is far from such an unachievable standard. It is a standard most of us can - and should - abide by.

However, suppose that a person does find it hard to abide by. The world is inhabited not only by standard people, but also by dangerous ones. It would of course be much better if a person with pedophiliac tendencies refused a position at a kindergarten. It would of course be preferable if a wealthy car owner with harassing tendencies did not hire a woman driver. Doesn't this contradict what I have been claiming throughout this essay?

Let's reconsider the description of our wealthy person: "no, he is no harasser. But he is a single, lonely man, and he wants to do his utmost to keep away from temptation, to make sure that he doesn't take advantage of an intimate situation he is not used to. As a measure of self-restraint, he decides to avoid hiring a female driver, just to be on the safe 
side." He is no harasser, yet he thinks of himself as a potential one. And he does nothing to improve his character traits. He takes a passive stance towards himself, as if he were a bystander looking at his conduct from the outside, saying to himself: "in such a case, this person tends to do x." 23

"This person" is himself. Thus, he is morally flawed if he adopts an outsider's perspective towards himself. His very personality is involved in his conduct. He should not just watch himself calmly, thinking to himself something like, "well, this is the person I am, what can I do?" As this is the person he is, there is plenty for him to do. He should do his utmost to improve himself. He can go into therapy; he might spend sleepless nights in anguish about who he is and who he would like to be. Such anguish would attest to his becoming a responsible agent. His therapist, or other experts, might advise him not to hire a woman until he is sure that harassing is out of the question to begin with. And they might be right. The problem with the wealthy person in our example is not his refusal to hire a woman per se, but his

${ }^{23}$ Such passivity is a characteristic of the case of "Professor Procrastinate," which might seem similar to the case I describe in this paper. The case is described by Frank Jackson and Robert Pargetter in their "Oughts, Options, and Actualism," and is modified in Jackson's "Procrastinate Revisited." To take the modified version: on Monday the Professor is asked to provide a tenure report, due on Friday. He is the best man for the job. Thus, the right thing for him to do on Monday is to say yes, and follow it up by preparing the report on time. But knowing his true character, the right thing for him to do on Monday is to refuse to make the report, and leave the job to Dr. Reliable, who is less qualified, but will make sure that it is done. Jackson (and Pargetter) discuss this paradox. All along, it is taken for granted that Procrastinate, as his name attests, has a given character. There is no difference between his beliefs about himself and other people's assessment of his character. 
unwillingness to take upon his own shoulders the burden of improving his character traits.

Working on our virtues is a task for each and every one of us. As I have claimed, not-even-contemplating-to-harass is hardly a high standard. It is something most of us can and should achieve. Public officials should surely pass this test, and should be expected to much more. What each of us does implicitly, they do out in the open. It is their job to construe the public sphere. The criticism with which the official's declaration (in the original case presented at the outset of this paper) was met attests to that. Not only did he offend women and act against notions of fairness and equality, his declaration manifested a certain world view that shifts the blame on the wrong party. If he had been the respectable person a public official should be, nobody would have imagined him to commit wrongful actions to begin with. If my analysis is sound, such conduct should characterize us all - public officials and private individuals alike.

\section{REFERENCES}

Jane H. Aiken (1984), "Differentiating Sex from Sex: the Male Irresistible Impulse," N.Y.U. Review of Law and Social Change 12, pp. 357-383

Michael E. Bratman (1987), Intentions, Plans, and Practical Reason, Cambridge, Mass.: Harvard University Press

Michael E. Bratman (2014), “Temptation and the Agent's Standpoint," Inquiry 57, pp. 293-310

J. P. Day (1993), “Temptation,” American Philosophical Quarterly 30, pp. 175-181 
Harry Frankfurt (1971), "Freedom of the Will and the Concept of a Person," The Journal of Philosophy 68, pp. $5-20$

Homer (2003), The Odyssey, translated by E. V. Rieu, revised translation by D. C. H. Rieu, London: Penguin

Paul M. Hughes (2002), “The Logic of Temptation," Philosophia 29, pp. 89-110

Paul M. Hughes (2004), "What Is Wrong with Entrapment," Southern Journal of Philosophy 42, pp. 4560

Frank Jackson (2014), "Procrastinate Revisited," Pacific Philosophical Quarterly 95, pp. 634-647

Frank Jackson and Robert Pargetter (1986), "Oughts, Options, and Actualism," Philosophical Review 95, pp. 233-255

A. T. Nuyen (1997), "The Nature of Temptation," Southern Journal of Philosophy 35, pp. 91-103

Saul Smilansky (1997), "Should I Be Grateful to You for Not Harming Me?”, Philosophy and Phenomenological Research 57, pp. 585-597

$(c c)$ EY 